\title{
Delocalized lipophilic cations as a new therapeutic approach in cancer
}

\author{
A Barbosa Ribeiro ${ }^{1 *+}$, A Luísa Ferreira $^{1 \dagger}$, A Cristina Gonçalves ${ }^{1,2}$, Sílvia Neves ${ }^{2,3}$, A Maria Araújo ${ }^{1}$, Filipa Carvalho ${ }^{1}$, \\ João Carvalho', Rui M Santos ${ }^{1}$, Vera Alves ${ }^{1}$, Teresa Silva ${ }^{1}$, José M Nascimento-Costa ${ }^{2,4,5}$, Ana B Sarmento-Ribeiro ${ }^{1,2,3}$ \\ From 16th International Charles Heidelberger Symposium on Cancer Research \\ Coimbra, Portugal. 26-28 September 2010
}

Delocalized lipophilic cations (DLCs) penetrate plasma and mitochondrial membranes and accumulate in mitochondria. The higher mitochondrial membrane potentials of neoplastic $v s$ normal cells, in general, account for greater uptake and may be a way to selectively target these cells since. Dequalinium (DQA) is a DLC and so our goal is to evaluate the therapeutic potential of DQA in cancer, namely in B-cell Chronic Lymphocytic Leukaemia (B-CLL), Acute Promyelocytic Leukaemia (APL) and Hepatocellular Carcinoma (HCC).

For this we used 3 cell lines, EHEB (B-CLL), HL-60 (APL) and HUH-7 (HCC), to evaluate the effect of different concentrations of DQA either by single dose administration, by daily dose administration and by association with conventional anticarcinogenic agents. Cell viability and death was determined by the resazurin assay, optical microscopy and by flow cytometry. The latter was also used to evaluate the mitochondrial membrane potential, the levels of $\operatorname{ROS}\left(\mathrm{H}_{2} \mathrm{O}_{2} ; \mathrm{O}_{2}{ }^{-{ }^{-}}\right)$and the antioxidant defense, Reduced Glutathione (GSH), using fluorescent probes.

We found that DQA induced a decrease in cell viability inducing cell death by late apoptosis/necrosis in a time, dose and cell type dependent manner, with and $\mathrm{IC}_{50}$ of $2.5,4.7$ and $7.5 \mu \mathrm{M}$ at $48 \mathrm{~h}$ of exposure, respectively to HL-60, HUH-7 and EHEB. These effects may be mediated by oxidative stress as we have observed and increase in ROS production and a decrease in GSH levels and in mitochondrial membrane potential. We also observed that if DQA is administered on a daily basis a much lower concentration is required to induce the same effect. On the other hand, the association of

\footnotetext{
* Correspondence: andremiguelmaster@gmail.com

† Contributed equally

${ }^{1}$ Faculty of Medicine (FMUC), University of Coimbra, Coimbra, Portugal
}

Full list of author information is available at the end of the article
DQA with the conventional drug induces a synergistic effect, because lower concentration of both drugs is required to obtain the some effect.

\section{Author details}

${ }^{1}$ Faculty of Medicine (FMUC), University of Coimbra, Coimbra, Portugal. ${ }^{2}$ Center for Investigation on Environment, Genetics and Oncobiology (CIMAGO), FMUC, Coimbra, Portugal. ${ }^{3}$ Center for Neuroscience and Cell Biology, Coimbra, Portugal. ${ }^{4}$ Medicine Service and Hepatology Unity, University Hospital of Coimbra, Coimbra, Portugal. ${ }^{5}$ University Hematology Clinic, FMUC, Coimbra, Portugal.

Published: 24 September 2010
Submit your next manuscript to BioMed Central and take full advantage of:

- Convenient online submission

- Thorough peer review

- No space constraints or color figure charges

- Immediate publication on acceptance

- Inclusion in PubMed, CAS, Scopus and Google Scholar

- Research which is freely available for redistribution

Submit your manuscript at www.biomedcentral.com/submit
C Biomed Central 